May 2001 • NREL/TP-550-30107

\title{
An Overview of Residential Ventilation Activities in the Building America Program (Phase I)
}

\section{Dennis Barley}

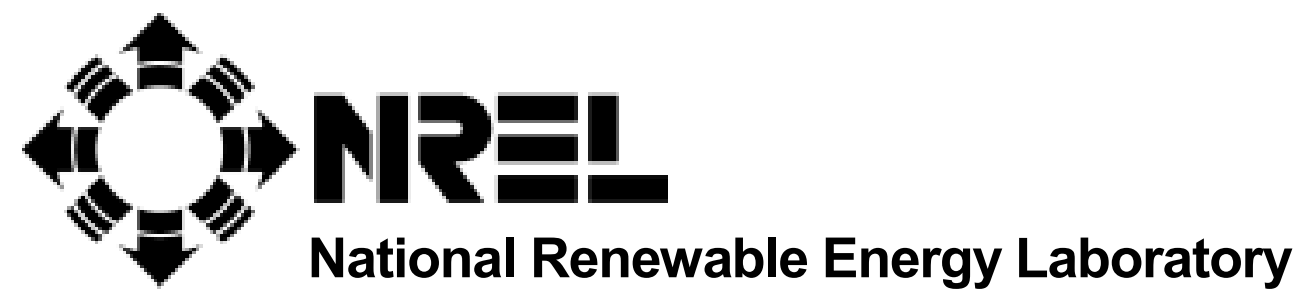

1617 Cole Boulevard Golden, Colorado 80401-3393

NREL is a U.S. Department of Energy Laboratory

Operated by Midwest Research Institute $\bullet$ Battelle $\bullet$ Bechtel

Contract No. DE-AC36-99-G010337 
May 2001 • NREL/TP-550-30107

\section{An Overview of Residential Ventilation Activities in the Building America Program (Phase I)}

\section{Dennis Barley}

Prepared under Task No. BET1.8004

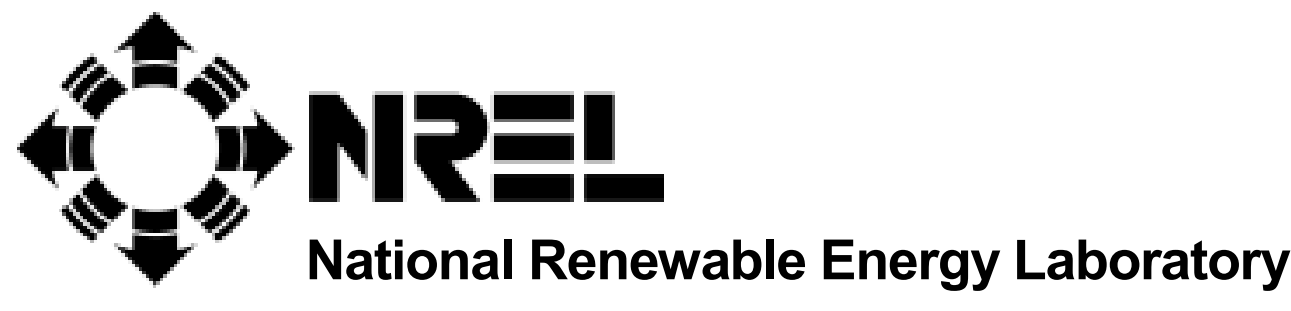

1617 Cole Boulevard

Golden, Colorado 80401-3393

NREL is a U.S. Department of Energy Laboratory

Operated by Midwest Research Institute $\bullet$ Battelle $\bullet$ Bechtel

Contract No. DE-AC36-99-G010337 


\section{NOTICE}

This report was prepared as an account of work sponsored by an agency of the United States government. Neither the United States government nor any agency thereof, nor any of their employees, makes any warranty, express or implied, or assumes any legal liability or responsibility for the accuracy, completeness, or usefulness of any information, apparatus, product, or process disclosed, or represents that its use would not infringe privately owned rights. Reference herein to any specific commercial product, process, or service by trade name, trademark, manufacturer, or otherwise does not necessarily constitute or imply its endorsement, recommendation, or favoring by the United States government or any agency thereof. The views and opinions of authors expressed herein do not necessarily state or reflect those of the United States government or any agency thereof.

Available electronically at http://www.doe.gov/bridge

Available for a processing fee to U.S. Department of Energy

and its contractors, in paper, from:

U.S. Department of Energy

Office of Scientific and Technical Information

P.O. Box 62

Oak Ridge, TN 37831-0062

phone: 865.576.8401

fax: 865.576.5728

email: reports@adonis.osti.gov

Available for sale to the public, in paper, from:

U.S. Department of Commerce

National Technical Information Service

5285 Port Royal Road

Springfield, VA 22161

phone: 800.553.6847

fax: 703.605.6900

email: orders@ntis.fedworld.gov

online ordering: http://www.ntis.gov/ordering.htm

Printed on paper containing at least $50 \%$ wastepaper, including $20 \%$ postconsumer waste 


\section{Preface}

The purposes of this report are to:

(1) Provide an overview of issues involved in residential ventilation;

(2) Provide an overview of the various ventilation strategies being evaluated by the five teams, or consortia, currently involved in the Building America program; and

(3) Identify unresolved technical issues.

This report does not identify a "best" approach to residential ventilation. Continued field testing and evaluation of various approaches in various climates seems likely to yield further understanding of the tradeoffs involved. Rather, the intent of this study is to aid in assimilating the thinking and experience in this area to date. All of the Building America teams have cooperated in assembling and reviewing the information in this report, which has been prepared at NREL between October 2000 and March 2001.

Plans for future phases of this study include (1) evaluating the ventilation test data that have been collected by NREL and the various Building America teams and (2) providing some guidance to the building industry regarding recommended approaches to residential ventilation. 


\section{TABLE OF CONTENTS}

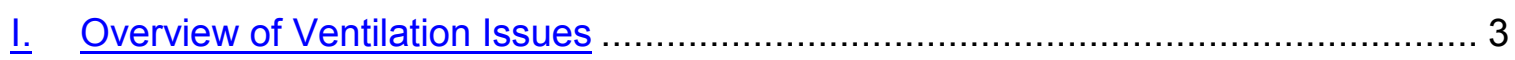

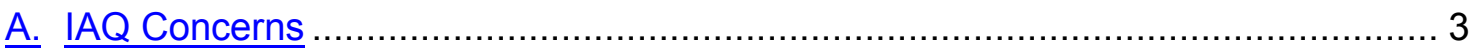

B. The Required Amount of Ventilation ............................................................... 4

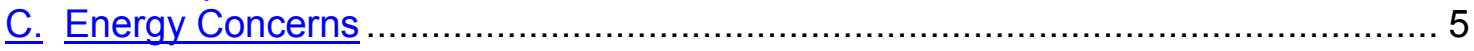

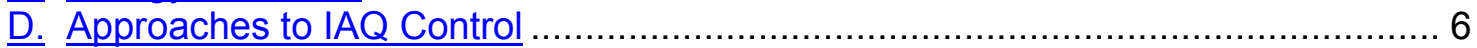

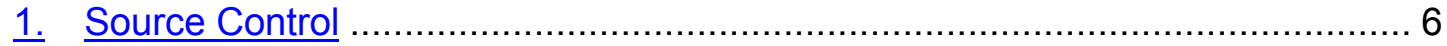

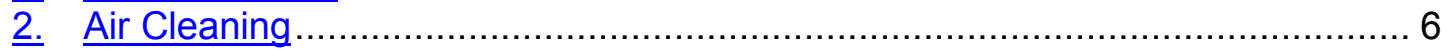

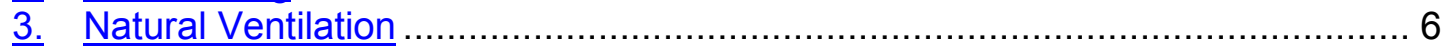

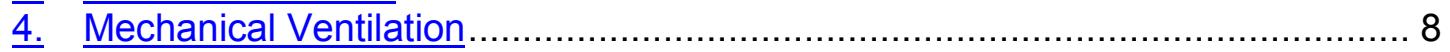

E. Heat/Energy Recovery ........................................................................ 10

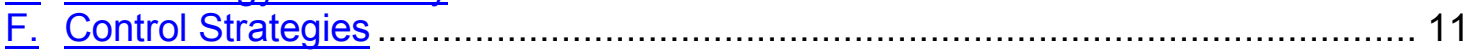

II. Common Ventilation System Configurations ………..................................... 12

1II. Overview of Building America Team Activities ……........................................... 14

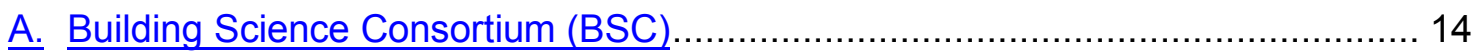

B. Consortium for Advanced Residential Buildings (CARB) .................................. 16

C. Hickory Consortium............................................................................... 17

D. Integrated Building and Construction Solutions Consortium (IBACOS) ................ 18

E. Industrialized Housing Partnership (IHP) ………..................................... 19

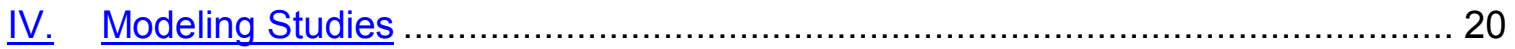

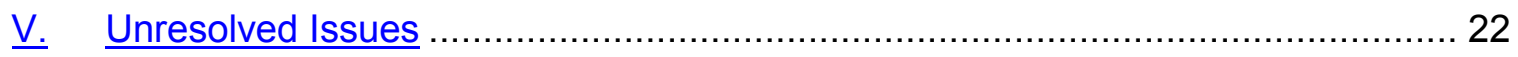

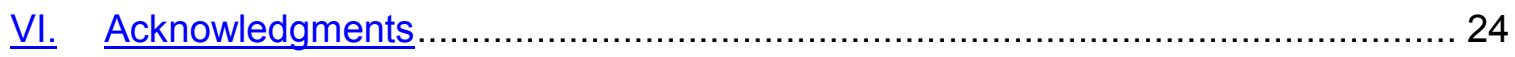

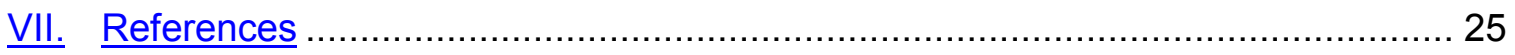

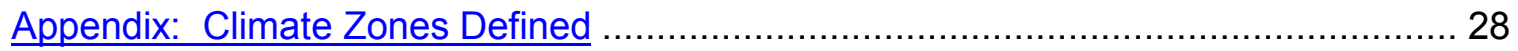




\section{Overview of Ventilation Issues}

In occupied buildings, ventilation (either natural or mechanical) is necessary to maintain acceptable indoor air quality (IAQ). At the same time, when buildings are heated or cooled, ventilation often constitutes a relatively large component of the heating or cooling load. In the past few decades, concerted efforts have been made to conserve energy by making buildings "tighter" (i.e., less prone to air leakage). Unfortunately, the success of that effort has exacerbated concerns about health, comfort, and other problems related to poor IAQ. The basic goal of the Building America program (Building America, 2000) is to foster the widespread construction of homes that are energy efficient, healthy, comfortable, and affordable. Thus, all of the Building America teams are making efforts to improve upon current practices by designing and implementing ventilation systems that provide adequate IAQ as energy efficiently and economically as possible. Numerous authors have discussed specific concerns and strategies toward this end (see References in Section VII). A brief overview of this material follows before the approaches of the various teams are described.

\section{A. IAQ Concerns}

People and pets need clean air to breathe. The primary challenge in designing ventilation systems is the control of pollutants that degrade air quality, in conjunction with the control of contaminant sources. A wide variety of pollutants from various sources must be maintained at sufficiently low concentrations for acceptable IAQ. Sources of indoor air pollutants include the following:

- Outside Air: Outdoor pollutants such as carbon monoxide (CO), sulfur dioxide $\left(\mathrm{SO}_{2}\right)$, oxidants (ozone), particulates, pollens, insecticides, herbicides, etc., may enter the building via natural or mechanical ventilation.

- Occupants: The people and pets that occupy buildings produce carbon dioxide $\left(\mathrm{CO}_{2}\right)$, odors, moisture, and pet dander (an allergen).

- Combustion: Combustion appliances such as fireplaces, furnaces, spot heaters, cook stoves, and water heaters generate $\mathrm{CO}_{2}, \mathrm{CO}$, various nitrogen- and sulfurcontaining by-products $\left(\mathrm{NO}_{\mathrm{x}}\right.$ and $\left.\mathrm{SO}_{\mathrm{x}}\right)$, moisture, particulates, etc. (These should be vented directly to the atmosphere, but problems in this regard are discussed below.) Cigarette smoke may also be listed as a combustion product.

- Building Materials and Furnishings: Particle board, fiberglass, asbestos, caulks, paints, gypsum joint compound, solder, fabrics, etc., may emit (by "outgassing" or "offgassing") volatile organic compounds (VOC's, including formaldehyde), particulates, and heavy metals such as lead and mercury, found mostly in older construction.

- Cleaning Compounds: Household cleaning products may emit VOC's or other chemicals.

- Surrounding Soil: Radon gas and moisture may enter the building through the basement or crawl space from the soil surrounding the building. 
- Pests: Dust mites, cockroaches, mice, and other pests, if present, can cause significant health problems through their allergens from fecal material, body parts, and urine.

Problems with excessive moisture in the air include microbes, such as mold, bacteria, and dust mites (an allergen), and condensation damage to the building structure (rot, mold, mildew, and ice build-up). Particulates may be classified as "inhaled particles," of size 10-20 microns (e.g., fiberglass, most pollens, dust mite feces), causing allergy-type symptoms, and "respirable particles," less than 10 microns in size (e.g., asbestos), causing more serious lung diseases.

\section{B. The Required Amount of Ventilation}

Numerous standards quantify the amount of ventilation that is required for acceptable IAQ. In the United States, where the Building America program is implemented, the predominant ventilation standard for site-built housing is ASHRAE 62 (ASHRAE, 1999). In addition, a new ventilation standard specifically for residences, ASHRAE 62.2P (ASHRAE, 2000), is currently in a draft and review stage. ASHRAE 62 provides two alternative criteria for determining an adequate amount of ventilation:

The ventilation rate procedure is the method most often used to meet the requirements of the standard. The basic criterion is to supply at least 0.35 air changes per hour (ACH) or $15 \mathrm{cfm}$ per person (whichever is greater), with some variation in these figures for special cases. In the public review draft of ASHRAE Standard 62.2P dated 8/11/00, the prescribed ventilation rate amounts to $15 \mathrm{cfm}$ per person plus $0.075 \mathrm{ACH}$. More recently, lower rates are being considered.

The indoor air quality procedure is an alternative to a prescribed rate of airflow in ASHRAE 62. With this method, a set of maximum allowable concentration levels for various pollutants serves as the criterion. A "demand control" approach to ventilation, based on this criterion, is discussed in Section I.F.7.

For manufactured housing in the United States, the applicable standard is HUD 24 CFR Part 3280 (HUD, 1994). This standard also stipulates a minimum of $0.35 \mathrm{ACH}$. An allowance is made for natural infiltration amounting to $0.25 \mathrm{ACH}$, which is to be supplemented by a mechanical ventilation rate of about $0.25 \mathrm{ACH}$. It is assumed that the combined effect of the two ventilation modes is $0.35 \mathrm{ACH}$, due to the interaction of pressure effects. (See Sherman and Modera, 1986, Equation 3.)

There is an unresolved issue regarding the consistency with which these ventilation rates must be provided: From an IAQ standpoint, is an average ventilation rate of 0.35 $\mathrm{ACH}$ adequate, or is a more consistent ventilation rate of $0.35 \mathrm{ACH}$ necessary? This is a complex matter involving medical research into the adverse health effects of extended exposure to various pollutants. However, it seems clear that several hours of exposure to an unpleasant odor would be regarded as a problem. HUD 3280.103 requires "a minimum of $0.35 \mathrm{ACH}$ continuously or at an equivalent hourly average rate." ASHRAE 62.2P gives mixed messages in this regard:

(1) "A mechanical ... system shall be installed to provide whole-building ventilation with outdoor air each hour at the rate specified..." 
(2) "The intermittent mechanical ventilation system must operate at least one hour out of every twelve."

(3) "If the cycle time is three hours or less, 1.0 can be used as the ventilation effectiveness."

The consistency requirement is an issue in both natural and mechanical ventilation systems.

In addition to the concern of introducing an adequate quantity of fresh air into a building, the distribution of that air within the building is also a concern. Air-Change Effectiveness, the degree to which a ventilation system delivers fresh air to all of the locations where it is needed, is addressed in ASHRAE Standard 129 (ASHRAE, 1997). Room-to-room distribution and air mixing within rooms are concerns in this regard. For example, Reardon and Shaw (1997) have compared a variety of residential ventilation systems based on multizone tracer gas testing. They conclude that "the local exhaustonly strategy ... [does] not provide adequate air distribution to the various individual rooms," and that "the rooms on the lower stories receive almost all of the outdoor air." In contrast with this conclusion, a modeling study of manufactured (one-story) homes by Persily and Martin (2000) shows reasonably good air distribution among rooms with a single-point exhaust fan. (The ratio of the room-to-room maximum to minimum airchange rates ranges from 1.3 to 1.6 in a variety of cases.) Various methods of testing multizone ventilation systems with single- and multiple-tracer gases are discussed by Sinden (1978), Harrje et al. (1985, 1990), and Fortmann et al. (1990). Techniques include:

- Single-tracer (often sulfur hexafluoride $\left(\mathrm{SF}_{6}\right)$ ), decay tests may be used to determine air-change effectiveness based on age-of-air analysis (Rudd and Lstiburek, 2000).

- Constant concentration single-tracer tests are used to determine rates of outside air entering each zone directly (See Harrje et al., 1985 \& 1990; Fortmann et al., 1990).

- Multiple-tracer tests are used to determine the matrix of airflow rates among the various zones and the atmosphere. These methods include the multitracer measurement system (MTMS) described by Sherman and Dickerhoff (1989) and the passive perfluorocarbon tracer (PFT) method described by Dietz et al. (1986).

\section{Energy Concerns}

In addressing the goal of energy-efficiency in ventilation system designs, two modes of energy consumption are considered:

Heating and cooling energy: In cold weather, fuel is consumed in heating outside air to the comfort level. In hot or humid weather, electricity is consumed in cooling and dehumidifying outside air to comfort levels. Approaches to minimizing these loads include (1) avoiding excessive ventilation rates and (2) using various heat and moisture recovery schemes. 
Air distribution energy: Blower power, and therefore electricity, is consumed when air is moved mechanically in a building for ventilation purposes. This concern may be addressed by (1) considering the use of natural ventilation, (2) avoiding excessive ventilation rates, (3) integrating ventilation systems with forced-air heating and cooling systems, (4) using more efficient blowers and ducting systems, and (5) placing and designing supply and return registers to maximize ventilation efficiency/effectiveness.

\section{Approaches to IAQ Control}

The most common approach to controlling IAQ is to replace or dilute polluted indoor air with fresh air from outside the building. This may be accomplished by either passive means (natural ventilation) or active means (mechanical ventilation). However, because of the energy concerns discussed above, source control and air cleaning are also considered. These four approaches are discussed below.

\section{Source Control}

Any method of preventing pollution from a particular source from mixing with the air to which occupants are exposed is referred to as source control. One approach to source control is exclusion, in which the source itself is either eliminated or isolated from the indoor environment. Replacing a material that outgases (such as particle board) with another less polluting material is one example of exclusion. Encapsulating fiberglass insulation within an airtight enclosure is another example. A second approach to source control is capturing pollution at the source. A fume hood over a cook stove or a chemical work area is an example of capturing pollution at the source. With the systems engineering approach used in the Building America program, source control measures are coordinated with the design of the mechanical ventilation system, with advantages in overall performance.

\section{Air Cleaning}

Air cleaning is any method that removes pollutants from the air to which building occupants are exposed, without replacing it. Filtration and dehumidification are two examples of air cleaning.

\section{Natural Ventilation}

Natural ventilation is the circulation of air in and out of a building by natural forces, unaided by mechanical equipment. The two primary forces that drive natural ventilation are thermal buoyancy and wind pressure. Ventilation driven by thermal buoyancy is often referred to as the "stack effect." When the indoor and outdoor air temperatures are different, the respective air densities differ accordingly. In cold weather, the warmer, less dense indoor air escapes through cracks, vents, or open windows higher in the building, while the cooler, denser outside air enters lower in the building. In buildings cooled in hot weather, the circulation pattern is reversed. Wind-driven ventilation occurs due to pressure differences around the outside perimeter that arise when the wind blows on a building. Higher pressures on the upwind side(s) drive air in through cracks, vents, or open windows, while lower pressures on the downwind side(s) draw air out of the building. The amount of ventilation arising from the wind and stack effects may be estimated using AHRAE Standard 136 (ASHRAE, 1993). A mathematical model developed at the Lawrence Berkeley National Laboratory (LBNL) (Sherman and Modera, 1986) is also useful in this regard. Diffusion of pollutants through the air might be regarded as an additional mode of natural pollutant removal, which would be active even 
when the stack and wind effects are null. No mention of this effect has been encountered as yet in the current study. This may be regarded as a topic for further study and perhaps research.

The obvious advantages of natural ventilation are its simplicity, economy, and quietness. Mechanical equipment, with its associated first cost, fan energy consumption, and noise, is avoided. The main disadvantage is that the rate of outside air exchange varies widely in a somewhat uncontrolled manner. An effort may be made to design a building envelope for an annual average ventilation rate of $0.35 \mathrm{ACH}$. However, at times when the indoor and outdoor temperatures are similar and there is no wind, there is virtually no driving force for the ventilation, so IAQ may be inadequate. Then, during very cold or windy periods, excessive ventilation may result. Three key issues remain unresolved:

- Is the variability of the ventilation rate a problem? See discussion in Section I.B.

- Does manual operation of windows or vents by occupants adequately control IAQ? It would seem that occupants can be relied upon to make adjustments to accommodate their own comfort. However, outdoor conditions such as noise, dust, rain, or security risks may be deterrents to opening windows. If the outdoor temperature is, say $55^{\circ} \mathrm{F}$, the stack effect may provide insufficient ventilation through cracks, but opening windows may create chilly drafts. If the outdoor temperature is, say $85^{\circ} \mathrm{F}$, the stack effect may provide insufficient ventilation through cracks, but high humidity may require air conditioning, which precludes opening windows. Another concern is pollutants that might pose health threats, even though their presence is not perceptible to the occupants. (Would an occupant open a window because the concentration of radon gas is too high?)

- Which approach is more energy efficient? It is unfortunate that the heating or cooling energy consumption per cubic foot of outside exchange air is highest in extreme weather, when overventilation is likely, and lowest in mild weather, when underventilation is likely. This adds energy inefficiency to the problem of a variable ventilation rate. How does this effect compare to the energy consumption of fans used in mechanical ventilation systems?

Current practice in the production housing industry is moving in the direction of mechanical ventilation. ASHRAE 62.2P asserts that:

"A mechanical exhaust system, supply system, or balanced system shall be installed to provide whole-building ventilation... Other methods may be used to provide the required ventilation rates ... when approved by a licensed design professional."

The HUD standard 24 CFR Part 3280.103 asserts that:

- Each manufactured home shall be capable of providing a minimum of 0.35 air changes per hour continuously or at an equivalent hourly average rate.

- Natural infiltration and exfiltration shall be considered as providing 0.25 air-changes per hour. 
- The remaining ventilation capacity may be provided by: a mechanical system, or a passive system, or a combination passive and mechanical system.

Three states now require mechanical ventilation systems: Minnesota, Vermont, and Washington (Andrews, 2000). All of the Building America teams are evaluating mechanical ventilation systems, which are discussed next. Even in a mechanical system, allowance for natural ventilation effects is part of the design process.

\section{Mechanical Ventilation}

A mechanical ventilation system uses one or more electrical blowers, and sometimes a system of ductwork, to move air in and out of a home. The primary advantage of this approach is the consistency and controllability of the rate of ventilation, provided that the building envelope is tight enough. If the natural ventilation rate is less than the desired amount of outside air at all times, then it is theoretically possible for a well-controlled mechanical ventilation system to consistently meet IAQ requirements without overventilating. Other advantages include opportunities to precondition outside air (filtration, dehumidification, preheating) and to apply various techniques of heat and energy recovery, as discussed below. The disadvantages are the cost of the mechanical equipment, the energy consumed by the blowers, the noise of operation, and perhaps maintenance requirements. Mechanical ventilation systems are of three basic types, as described below. Advantages and disadvantages of these approaches are summarized in Table 1.

In an exhaust ventilation system, a fan is used to blow air out of the building. This creates a negative pressure within the building, relative to the outside air. Typically, a standard bathroom fan is upgraded to one that is suited for continuous (or timed) operation at a low speed, with a manual control that occupants may use to run the fan at high speed as needed. Makeup air enters the building either through cracks in the building envelope or through one or more passive vents. Advantages of this approach include:

$+\quad$ The ease and economy with which it may be implemented.

+ The "transpired solar collector" effect: In cold weather, makeup air may be heated in its passage through a wall that is warmed by solar radiation.

Possible problems with this approach include:

- Combustion products that would normally be vented through chimneys may be drawn inside the building by the negative pressure differential. To avoid such backdrafting, sealed or power-vented combustion appliances may be needed.

- In hot, humid climates where air conditioning is used, warm, moist outside air drawn in through cracks may condense on cooler surfaces within the structure (walls, roof or attic), causing damage such as mold, mildew, or rot.

- Moisture and radon gas from the ground, $\mathrm{CO}$ from an attached garage, etc., may be drawn into the building by the negative pressure differential. 
In a supply ventilation system, a fan is used to blow air into the building. This creates a positive pressure within the building, relative to the outside air. Air leaves the building either through cracks in the building envelope or through one or more passive vents. In addition to avoiding the problems listed above for exhaust systems, supply systems have the advantage that:

+ The path of the incoming air is controlled; thus, it can be filtered, heated, or otherwise conditioned before it is introduced to the occupants.

Possible problems with supply ventilation include:

- In cold climates, the positive pressure differential may drive warm, moist air from the interior of the building out through cracks, where it may condense on cold surfaces within the structure (walls, roof, or attic), causing damage such as mold, mildew, rot, and ice buildup.

- Spot exhaust fans used in bathrooms, range hoods, and clothes dryers may intermittently create a negative pressure, defeating the effort to maintain a positive pressure and creating some of the problems listed above for exhaust systems.

In a balanced ventilation system, both intake and exhaust fans are used to maintain a neutral pressure within the building.

+ This approach may avoid all of the problems arising from either a positive or negative pressure difference (see exceptions, below).

Possible problems with balanced systems include:

- $\quad$ The expense of the additional equipment and electrical operating power.

- In some so-called balanced systems, the supply and exhaust fans are operated at different times, so that positive and negative pressures are created intermittently. In this report, these systems are referred to as "intermittently balanced" (see Sections II and III). What is the cumulative effect of such intermittent pressure imbalances? Some of the same problems noted above for unbalanced systems will occur in intermittently balanced systems. For example, the drawing in of combustion products during depressurization will not be undone in the pressurized mode. Likewise, condensation caused in one mode may not be undone in the opposite mode.

- Whereas exhaust and supply systems achieve some degree of fresh air distribution by routing air through cracks in the building shell, a balanced system may require some additional ductwork to achieve this, depending on the configuration.

- Depending on the locations of the air supply and exhaust ports, room-to-room pressure variations may occur, possibly causing some of the problems of pressurized and depressurized systems.

All three of these basic system types are being evaluated by the Building America teams in various climates, as is discussed in Section III. 


\begin{tabular}{|c|c|c|}
\hline System Type & Advantages & Disadvantages \\
\hline Exhaust & $\begin{array}{l}\text { - Easy and inexpensive } \\
\text { - Transpired solar collector } \\
\text { effect }\end{array}$ & $\begin{array}{l}\text { - May entrain pollutants from } \\
\text { combustion, garage, ground } \\
\text { (moisture, radon) } \\
\text { - Moisture damage to structure in hot- } \\
\text { humid climates }\end{array}$ \\
\hline Supply & $\begin{array}{l}\text { - Can precondition outside air } \\
\text { - Resists entraining pollutants }\end{array}$ & $\begin{array}{l}\text { - Moisture damage to structure in cold } \\
\text { climates } \\
\text { - Spot exhaust fans counteract positive } \\
\text { pressure }\end{array}$ \\
\hline Balanced & $\begin{array}{l}\text { - Avoids pressurization/ } \\
\text { depressurization problems }\end{array}$ & $\begin{array}{l}\text { - More expensive (equipment, fan } \\
\text { power) } \\
\text { - Intermittent pressurization in some } \\
\text { - } \text { systems } \\
\text { - May require distribution ductwork } \\
\text { - Possible spatial pressure variations }\end{array}$ \\
\hline
\end{tabular}

\section{E. Heat/Energy Recovery}

In addressing the Building America goal of energy efficiency, there are several design options available for recovering heat, coolness, and moisture from exhaust air and/or preconditioning supply air with the same. With an air-to-air heat exchanger, incoming and outgoing ventilation air streams are brought into thermal contact in a device such as a crossflow (or other type) heat exchanger. In cold weather, the outgoing exhaust air preheats incoming outside air; in hot weather, the outgoing exhaust air precools incoming outside air. Two blowers may be used to drive the air streams, providing balanced ventilation to the home. An energy exchanger transfers moisture between the incoming and outgoing air streams, in addition to heat. This is usually accomplished with a rotating wheel, regenerative heat exchanger that has the additional capacity to absorb and release moisture. In either case, some sort of ductwork is needed to bring the exhaust and supply air streams together at the exchanger and to distribute the ventilation air throughout the house. In some designs, air is ducted to and from the main return duct. This raises the concern of possible short-circuiting of the ventilation air, resulting in very poor ventilation efficiency.

Another heat recovery option is the use of a heat pump to extract heat from the exhaust air. The recovered heat may be used for space heating or domestic hot water heating. An additional approach is tempering incoming air by channeling it through an earthcoupled air intake duct, i.e., an air duct buried in the ground. Because the ground temperature is generally more moderate than the outside air temperature, hot-humid air 
can be precooled in the summer, and cold air can be preheated in the winter with this approach. In all of the heat recovery schemes, design concerns include:

- The initial expense of the hardware;

- The requirement for additional ductwork, with the associated cost and space requirements;

- The power consumed by the device versus the energy saved;

- Maintenance requirements; and

- Condensation of moisture in devices that cool air.

\section{F. Control Strategies}

Theoretically, with a tight enough building and mechanical ventilation, it should be possible to maintain adequate IAQ without detracting from energy efficiency by overventilating. In practice, a variety of control strategies are used to approach this goal. Some of these are as follows.

1. Manual control by occupants. This approach is typically used with spot ventilators, such as bathroom fans and range hoods. It may also be used for whole-house ventilation, especially where an upgraded bathroom fan is used for this purpose. Advantages include simplicity, low cost, and the ability of occupants to have ventilation whenever they want it. A disadvantage is the likelihood of underventilation if occupants do not understand the need for whole-house ventilation, are not sufficiently sensitive to $\mathrm{IAQ}$ problems such as health risks and moisture damage, or forget to turn it on.

2. Continuous operation, $24 \mathrm{hrs} /$ day. This approach has the advantage of consistency in maintaining some level of IAQ. One disadvantage is the power consumption of the constantly running fan. For an upgraded bathroom fan, this may amount to about 60 watts ( $\$ .10$ per day at $\$ .07$ per kilowatt hour). In a forced-air-integrated ${ }^{1}$ ventilation system, however, this may amount to several hundred watts. Also, ventilation is provided even when no one is home, which may not be necessary, ${ }^{2}$ at the expense of both fan energy and heating or cooling energy.

3. Scheduled operation. With this strategy, the ventilation fan is run on a programmable daily schedule. Typically, this schedule coincides with normal hours of occupancy. This approach has the advantage of consistently and efficiently providing ventilation and consuming energy only when the ventilation is needed. ${ }^{2}$ A disadvantage would be that any variation in the occupancy schedule (such as a sick day at home or a vacation away from home) would detract from the effectiveness of the control.

4. Duty cycle. With this strategy, the ventilation fan is run for some period of time, typically 15 to 30 minutes, in each hour. Accordingly, the ventilation rate is adjusted so that the hourly average rate meets the requirement of the applicable standard. This approach provides consistency of ventilation similar to that of continuous operation, but with less fan power consumption. An example of this approach is the fan recycler control often used in force-air-integrated ventilation systems. The main blower is run for

\footnotetext{
${ }^{1}$ For a definition of forced-air-integrated systems, see Section II, item "Sfa."

${ }^{2}$ While ASHRAE Standard 62 addresses unoccupied periods in Section 6.1.3.4, the tentative new Standard 62.2P does not.
} 
some minimum time each hour, even if heating or cooling is not needed. This regulation provides some ventilation in each hour while economizing on blower power, relative to running the blower continuously.

5. Thermostat control. In forced-air-integrated ventilation systems, ventilation is provided when the main blower runs. If no other type of control is applied, ventilation occurs only when a heating or cooling load is being met. This approach has the advantage that no additional blower power is used for ventilation. The main disadvantage is that little or no mechanical ventilation is provided during periods of mild weather. (Unfortunately, this is the same time when natural ventilation has the least effect, unless windows are opened.)

6. Occupancy sensor. Improving somewhat on the scheduled operation strategy, an occupancy sensor runs a ventilation fan whenever people are present. The advantage of this approach is that ventilation is provided when it is needed, and energy is conserved when ventilation is not needed (see footnote 2 on the previous page).

7. Demand control. With this approach, one or more sensors are used to detect pollutant levels and dynamically control the ventilation system to maintain pollutant concentrations below acceptable thresholds (Emmerich and Persily, 1997). This approach is potentially the most energy-efficient ventilation control strategy that provides consistently adequate IAQ. Excessive ventilation is avoided at times of low occupancy or vacancy, whereas increased ventilation is provided at times of high occupancy. Because it is not practical to monitor and control all pollutants, demand-controlled ventilation systems use one or more surrogate indicators of IAQ. $\mathrm{CO}_{2}$ concentration is used in this regard in some commercial buildings (Strindehag et al., 1990; Strindehag and Persson, 1989) and has been used experimentally in residential buildings (Koontz et al., 1995; O'Neill, 1995). However, $\mathrm{CO}_{2}$ control is generally regarded as impractical for residences because of the expense of the required sensor and the need for frequent sensor recalibration. Schell and Int-Hout (2001) report that the cost of $\mathrm{CO}_{2}$ sensors has dropped about $50 \%$ in the past 3 years. Some research into lower-cost methods of demand control is underway (source confidential).

8. Humidistat control. This type of controller is used to turn on a ventilation system when the indoor humidity exceeds some reference level.

9. Zone control. Because the occupants of a home are expected to be in bedrooms during certain hours and in other rooms during other hours, it may be energy-efficient to ventilate these areas on separate schedules. One of the Building America teams has used this approach, in conjunction with a zoned heating and cooling system. (See the description of the Crosswinds Community project in Section III.B.)

\section{Common Ventilation System Configurations}

Some basic configurations for mechanical ventilation systems are described in this section. A symbolic naming convention, adapted from Roberson et al. (1998, discussed in Section IV), is introduced here for subsequent use in summarizing the strategies of the various teams across the various climate zones. (See Table 2, with further details given in Section III.) Note that a description of the five climate types cited in Table 2 is included in the Appendix. 
Ebr: Exhaust ventilation is provided by an upgraded bathroom exhaust fan that is designed for long life, low noise, and multispeed operation. A controller is used to run the fan at a low speed on a programmable timer schedule for whole-building ventilation, with a manual switch the occupants can use to run the fan at a higher speed for spot ventilation when desired.

Esp: Exhaust ventilation is provided by a single-port exhaust fan, centrally located in the building, that runs continuously or on a timer.

Emp: Exhaust ventilation is provided by a multiport exhaust fan that is ducted to several bathrooms. A controller is used to run the fan at a low speed on a programmable timer schedule for whole-building ventilation, with manual switches the occupants can use to run the fan at a higher speed for spot ventilation when desired.

Ssp: Supply ventilation is provided by a single-port supply fan, centrally located in the building, that runs continuously or on a timer.

Sfa: Supply ventilation is provided through the ductwork of a forced-air heating/cooling system. Outside air enters through a small duct that feeds into the main return duct near the air handler. This configuration is sometimes referred to as "forced-air-integrated supply ventilation."

Sfa-f: An Sfa system in which an additional, smaller fan supplies outside air through a small duct that feeds into the main return duct near the air handler. This fan may be operated in conjunction with the air handler or on a separate timer control, depending on the design.

Sfa-r: An Sfa system in which a fan recycler control ensures that the main blower runs for some time (typically 15-30 minutes) each hour, even if heating or cooling is not needed at that time.

Sfa-i: An Sfa-r system in which the conventional blower motor is replaced with a more expensive integrated control motor (ICM). ${ }^{3}$ This type of blower runs more efficiently at lower speeds, reducing the blower power consumption for ventilation.

Sfa-fr: A combination of the Sfa-f and Sfa-r approaches, using both an additional outside air supply fan and a fan recycler control.

Smp: Supply ventilation is provided through a multiport system of ventilation ductwork. A small fan supplies outside air to the duct system, either continuously or on a timer.

Bfa: Balanced ventilation is provided with an Sfa type of supply system plus an exhaust fan.

Bfa-r: Balanced ventilation is provided with an Sfa-r type of supply system plus an exhaust fan.

${ }^{3}$ The ICM is a newer version of the electronically commutated motor (ECM). 
Bfa-i: Balanced ventilation is provided with an Sfa-i type of supply system plus an exhaust fan.

Bfa-f: Balanced ventilation is provided with an Sfa-f type of supply system plus an exhaust fan.

Bmp: Balanced ventilation is provided with an Smp type of supply system plus singleport exhaust fan.

Bhr: Balanced ventilation is provided with a heat recovery or energy recovery ${ }^{4}$ ventilation unit.

i: $\quad$ Prefix indicates an intermittently balanced system, in which exhaust and supply fans may operate at different times.

+: $\quad$ Suffix indicates additional advantageous features included in a particular design, as described in Section III.

\$: Prefix indicates a more expensive approach that may be more appropriate in a higher-price-range housing market.

( ): Indicates a strategy that is less preferred by the team than other approaches.

\section{Overview of Building America Team Activities}

In the Building America program, all of the teams are engaged in ongoing testing of a variety of ventilation system types. In general, the teams are (1) constructing tight buildings, (2) providing mechanical ventilation systems, and (3) controlling the rate of ventilation to address the goals of $I A Q$ and energy efficiency. However, the specific designs vary across climate regions and among the teams. The choice of an approach often involves a compromise between the engineering goals of the team and cost constraints that are imposed by the builders and the housing market. A summary comparison of these approaches is shown in Table 2, with design details discussed below. The symbolic naming convention for the basic system configurations is defined in Section II, and a description of five climates that are cited is included in the Appendix. Heating and cooling systems are forced air, unless otherwise noted.

\section{A. Building Science Consortium (BSC)}

BSC recommends building envelopes with airtightness of less than 0.25 cubic feet per minute (cfm) per square foot of building surface area (including floor area below grade) at a pressure difference of 50 pascals $(\mathrm{Pa})$, with no more than $5 \%$ duct leakage to the outside. Mechanical ventilation is provided for a rather conservative $10 \mathrm{cfm}$ per person, unless a higher rate of up to $20 \mathrm{cfm}$ per person is called for by the occupants or by special circumstances (e.g., pets). The preferred approach to ventilation is to make use of forced-air heating ductwork to distribute ventilation air throughout the building, in conjunction with a fan recycler control. Proper equipment sizing, lower velocity airflow,

4 "Energy recovery" includes moisture transfer between the ingoing and outgoing airstreams. 
and strategic placement of air registers have avoided any cold draft problems, in 3 years of BSC experience. Variations of this basic approach, as described below, include supply, exhaust, and intermittently balanced ventilation systems. Several measures are applied to mitigate adverse effects of pressurization or depressurization:

- All combustion appliances within conditioned spaces are sealed.

- In supply systems, the outside air quantity is limited, in conjunction with the tightness of the shell, to limit the pressurization to about 0-1 $\mathrm{Pa}$.

- The building envelope is designed to alleviate moisture problems. In cold climates, more permeable materials are used toward the outside of the shell to facilitate drying to the less humid outside air. In warm humid climates, the more permeable materials are located toward the inside of the shell to facilitate drying to the less humid indoor air.

- In cold climates, the indoor relative humidity is maintained at no more than $35 \%$.

Table 2: Summary of Ventilation Tests

\begin{tabular}{|c|c|c|c|c|c|c|c|}
\hline $\begin{array}{l}\text { Team: } \\
\text { Climate }\end{array}$ & BSC & $\underline{\mathrm{CARB}}$ & Hickory & IBACOS & $\underline{\mathrm{IHP}}$ & $\frac{\text { Roberson }}{\text { et. al }}$ & $\frac{\text { Wray }}{\text { et. al }}$ \\
\hline $\begin{array}{l}\text { Severe- } \\
\text { Cold }\end{array}$ & iBfa-r & & & & Ebr & & $\begin{array}{c}\text { Esp,Ebr, } \\
\text { Bhr }\end{array}$ \\
\hline Cold & Sfa-r+ & $\begin{array}{c}\text { Emp } \\
\text { iBfa+ } \\
\text { \$Bfa-i+ } \\
\end{array}$ & Ebr, iBfa-f & $\begin{array}{c}\text { Bhr,Bfa } \\
\text { Ssp, Sfa-r } \\
\text { Ebr } \\
\end{array}$ & Ebr & Bmp, \$Bhr & $\begin{array}{c}\text { Esp,Ebr, } \\
\text { Bhr }\end{array}$ \\
\hline $\begin{array}{l}\text { Mixed- } \\
\text { Humid }\end{array}$ & & & & $\begin{array}{c}\text { Sfa,Sfa-r } \\
\text { Bhr }\end{array}$ & Ebr & $\begin{array}{c}\text { Smp } \\
\text { (Sfa-r, } \$ \text { Sfa-i) }\end{array}$ & $\begin{array}{c}\text { Esp,Ebr, } \\
\text { Bhr }\end{array}$ \\
\hline Hot-Humid & Sfa-r & & & Sfa-fr & Esp, Sfa & $\begin{array}{c}\text { Smp } \\
\text { (Sfa-r, } \$ \text { Sfa-i) }\end{array}$ & Bhr \\
\hline $\begin{array}{l}\text { Hot/Mixed } \\
\text { Dry }\end{array}$ & Sfa-r,Esp+ & $\mathrm{iBfa}+$ & & Bhr,Sfa-r & & $\begin{array}{c}\text { Smp } \\
\text { (Sfa-r, } \$ \text { Sfa-i) }\end{array}$ & $\begin{array}{c}\text { Esp,Ebr, } \\
\text { Bhr }\end{array}$ \\
\hline
\end{tabular}

Note: Symbols are defined in Section II, and particular designs are described in more detail in Sections III and IV.

Specific ventilation system designs are as follows:

Cold, Hot-dry, and Hot-humid climates: Sfa-r

Central-fan-integrated supply ventilation is implemented by an outside air intake into the main return duct, with a fan recycler control to run the main blower on a prescribed duty cycle when heating or cooling demands are not running the fan. The amount of outside air is based on the estimated duty cycle, with an allowance for $0.1 \mathrm{ACH}$ of natural ventilation. This approach was used in the Prairie Crossing project in Grayslake, Illinois, 
and in the Centennial Crossing project in Chicago, Illinois (Cold climate), in several projects in Hot-dry climates, ${ }^{5}$ and in the East Hampton project in Jacksonville, Florida (Hot-humid climate).

Severe-cold climate: iBfa-r

In several projects in Minneapolis, ${ }^{6}$ Minnesota, BSC applied an intermittently balanced ventilation approach. A single-point exhaust fan operates continuously, in conjunction with the intermittent operation of the central-fan-integrated supply approach described above.

Mixed-dry climate: Esp+

In the Lee Group/Braemar Urban Ventures, Village Green project in Los Angeles, California, single-point exhaust ventilation was used, with central fan recycling for air distribution.

\section{B. Consortium for Advanced Residential Buildings (CARB)}

The general approach pursued by CARB involves working with builders to reduce natural infiltration rates below $0.35 \mathrm{ACH}$. Mechanical ventilation systems are designed to provide up to $0.35 \mathrm{ACH}$. These systems are flexible in capacity, with opportunities to adjust fan speed and duty cycle for different levels of house tightness and occupant needs and preferences.

\section{Cold climate: Emp, iBfa+, \$Bfa-i+}

For the Ryan Homes, Beaver Creek project in Rochester, New York, CARB installed exhaust ventilation systems. A multiport exhaust fan, installed in the attic, is ducted to exhaust vents in two bathrooms. Makeup air enters the building by infiltration through cracks in the building. A controller is used to run the fan at low speed on a programmable timer schedule, with manual switches the occupants can use to run the fan at high speed when desired. No open combustion systems are installed within the conditioned space. Both the water heater and the furnace are direct-vent sealed combustion systems located in the basement.

For the McStain Enterprises, MeadowView project in Longmont, Colorado, CARB installed a lower-cost version of the multiport exhaust fan, along with an outside air duct to the main return duct. This approach features single-speed fans with a Grasslin electromechanical timer control for establishing a duty-cycle for whole-house ventilation. Crank timers are installed in each bathroom for manual control of spot ventilation. Once again, both the water heater and the furnace are direct-vent sealed combustion systems located in the basement.

For the Andover Woods, Crosswinds Community project in Detroit, Michigan, CARB installed balanced ventilation systems. Outside air is drawn in through a small duct to the main return duct, and distributed to two zones within the building via the HVAC

${ }^{5}$ Locations and projects include: Watt Homes, Four Seasons subdivision and Pulte Homes, Cyprus Point, Crown Ridge, and Boulder Mountain projects in Las Vegas, NV; Pulte Homes, Arroyo Ridge and Spanish Trails projects in Tucson, AZ.

${ }^{6}$ The builders include Pulte Home Corp., Centrex Homes, and Town \& Country Homes; subdivisions include The Grove at Elm Creek, Regatta, and Eden Prairie. 
ductwork. Air is actively exhausted by a single upgraded bathroom fan. Two separate zone controllers run the air handler, bathroom fan, and a motorized damper in the outside air duct together on programmable timer schedules. The two-stage, sealed combustion furnace in the basement includes an electronically commutated motor (ECM) blower to reduce the blower power consumed for ventilation.

Hot-dry climate: iBfa+

For the Del Webb Corp., Sun City Grand project in the Phoenix, Arizona area, CARB installed intermittently balanced ventilation systems. A multiport exhaust fan, installed in the attic, is ducted to exhaust vents in two bathrooms. A 4-inch outside air duct to the return plenum includes an airflow regulator to limit the quantity of outside air brought in during air-handler operation. A controller is used to run the fan at low speed on a programmable timer schedule. Occupants can use manual switches to run the fan at high speed when desired. No open combustion systems are installed within the conditioned space. The atmospheric water heater (which also heats the home via a hydronic coil in the air stream) is installed in the garage.

\section{Hickory Consortium}

The general approach pursued by Hickory involves designing the building envelope for an annual average of about $0.2 \mathrm{ACH}$. Then, in determining the amount of mechanical ventilation to provide, the combined effect of natural and mechanical ventilation is estimated as follows:

$$
\begin{aligned}
& \text { Qtotal = Qbal + Maximum of (Qunbal, Qws +.5 Qunbal) } \\
& \text { where Qtotal } \\
& \begin{array}{ll}
\text { Qbal } & =\text { total ventilation rate } \\
\text { Qunbal } & =\text { either Qsupply or Qexhaust }
\end{array} \\
& \begin{array}{ll}
\text { Qupply } & =\text { unbalanced mechanical ventilation rate due to supply } \\
\text { Qexhaust } & =\text { unbalanced mechanical ventilation rate due to exhaust } \\
\text { Qws } & =\text { average natural ventilation rate due to wind and stack effects }
\end{array}
\end{aligned}
$$

Cold climate: $E b r$

In the CWC/Thomas Construction, Erie-Ellington project in Boston, Massachusetts, hydronic heating systems are used. Here, Hickory installed exhaust ventilation systems, using upgraded bathroom fans and relying on natural infiltration for the makeup air. A controller is used to run the fan at low speed on a programmable timer schedule. Occupants can use manual switches to run the fan at high speed when desired. Combustion appliances are sealed to prevent backdrafting.

\section{Cold climate: iBfa-f}

In two Epoch Corporation, urban in-fill projects in Cambridge, Massachusetts, forced-air heating is used. Here, Hickory installed intermittently balanced exhaust systems. The same type of bathroom exhaust fan and control described above is augmented in these projects with a supply fan in a small outside air intake duct to the main return duct. The supply blower is controlled by an independent timer. With this type of control, positive, negative, and neutral pressurizations occur on a random basis, according to the actions of the two independent timers. In the Cambridge co-housing project, there are no combustion appliances in the conditioned space. (A central, ground-water heat-pump 
system is used to supply the conditioned water to all the units.) In the Elm Street housing projects, sealed combustion units are used for generating heated water.

\section{Integrated Building and Construction Solutions Consortium (IBACOS)}

IBACOS describes its approach as "case-by-case," rather than promoting any particular approach to ventilation. The goal for airtightness is one of the variables, as noted in each case below. In addition to climate, the price range of the target housing market is a key factor in the design decisions. All houses have bath fans and kitchen hoods with ducted exhaust to outside. A variety of whole-house ventilation systems designs are described as follows.

Cold climate: Bhr, Bfa, Ssp, Sfa-r, Ebr

In Pulte Homes projects in Grand Rapids, Michigan, IBACOS installed two types of ventilation systems:

1. Balanced systems with heat recovery ventilation. Air is ducted to and from the main return duct by the heat-recovery ventilation (HRV) unit. Airtightness was tested as 4 $\mathrm{ACH}$ at $50 \mathrm{~Pa}$.

2. Forced-air-integrated supply ventilation, with an outside air duct to the main return duct and a fan recycler control. Airtightness was tested as $4 \mathrm{ACH} 50$.

In the Farm Development project in Albany, New York, and in the Heartland project in Pittsburgh, Pennsylvania, IBACOS will install forced-air-integrated supply ventilation, with an outside air duct to the main return duct, a motorized damper, and a fan recycler control. Airtightness was designed for $4 \mathrm{ACH} 50$.

In the Summerset at Frick Park project in Pittsburgh, Pennsylvania, IBACOS will install exhaust ventilation systems using upgraded bathroom fans with a makeup air inlet in the basement. Radon pipes will be installed under the basement floor, and all combustion appliances will be sealed. The design infiltration rate is $2.5 \mathrm{ACH} 50$.

In the Estridge Homes project in Indianapolis, Indiana, IBACOS is comparing a variety of ventilation system designs. In addition to the Sfa-r and Bhr systems discussed above, these include:

1. Single-port supply ventilation is provided constantly to the foyer ceiling.

2. Forced-air-integrated balanced ventilation is provided by an air exchanger, which exhausts air from the basement and supplies outside air to the main return duct.

Mixed-humid climate: Sfa, Sfa-r, Bhr,

In several projects in the Mixed-humid climate region, IBACOS installed forced-airintegrated supply ventilation, with an outside air duct to the main return duct. These include:

1. The Hedgewood Properties, Edmund Park project in Atlanta, Georgia:

Fan recycler, no motor damper, tested $6 \mathrm{ACH} 50$.

2. The Venture Homes, Cyprus Club project in Atlanta, Georgia:

No fan recycler, no motor damper, tested $8 \mathrm{ACH} 50$

3. The Fortis project in High Point, North Carolina:

Fan recycler, motorized damper, designed for $4 \mathrm{ACH} 50$. 
In the Hedgewood Homes, New American Home project in Atlanta, Georgia, IBACOS used an energy recovery ventilation unit ducted to the main air return of two air-handling units (AHU's). Airtightness was tested as $6 \mathrm{ACH} 50$.

\section{Hot-humid climate: Sfa-fr}

In a Medallion Homes, Mainland Square pilot house in San Antonio, Texas, IBACOS installed forced-air-integrated supply ventilation. A supply blower feeds outside air into the main return duct. A fan recycler controller operates both the air handler and the fresh air intake fan at least 25 or 30 minutes per hour. Airtightness was tested as $4 \mathrm{ACH}$ 50 .

Hot-dry climate: Bhr, Sfa-fr

In a U.S. Army, Yuma, Arizona Proving Ground demonstration house, balanced ventilation will be provided by an HRV unit that exhausts air from a bathroom and supplies fresh air to the main air return duct. Airtightness was designed for 2 ACH 50 .

In the RGC, Civano project in Tucson, Arizona, IBACOS installed forced-air-integrated supply ventilation, with a supply blower feeding outside air duct to the main return duct and a 24-hour timer control (less sophisticated than a fan recycler control). Airtightness was tested as $2.7 \mathrm{ACH} 50$.

\section{E. Industrialized Housing Partnership (IHP)}

IHP works primarily with builders of manufactured housing, where the goal of cutting costs seems paramount. Low-cost exhaust ventilation systems are used in almost all cases to meet the Department of Housing and Urban Development (HUD) code mechanical ventilation requirement (HUD 1994). Combustion appliances are generally in the conditioned space. Furnaces and waters are generally in closets with provisions for outside combustion air, whereas wood fireplaces generally do not have outside combustion air. Two projects in different climate regions are described below.

Severe-cold, Cold, and Mixed-humid climates: Ebr IHP provides technical assistance to "Super Good Cents" manufactured housing in the Pacific Northwest region, including Idaho, Montana, Oregon, and Washington. Their general approach is to design the building envelope for about $0.2 \mathrm{ACH}$, and to provide an additional $0.25 \mathrm{ACH}$ of mechanical ventilation to meet the HUD standard. Exhaust ventilation is implemented with an upgraded bathroom fan (1.0 sone noise rating), which is controlled by a programmable timer or an on-off switch at the discretion of the occupants. Make-up air enters the building through leakage paths in the building envelope. Occupants are provided with instructions and well-labeled controls.

Hot-humid: Esp, Sfa

In the southeastern United States, builders of manufactured housing are experiencing serious problems with moisture damage. This appears to be the result of a combination of factors prevalent in standard practice: 
- The use of exhaust ventilation systems. An upgraded bathroom fan is installed in a utility room or hallway, with make-up air entering through cracks in the building.

- Leakage of air supply ducts to the outside and inadequate return air transfers, which further depressurizes the building.

- A vinyl veneer on the inside wall surface, behind which condensation causes mold and mildew growth.

So far, builders have expressed interest in intervention by the Building America program only to the extent that it addresses this existing problem, without increasing construction costs. IHP is working with several manufacturer partners on several remedial measures:

- Sealing air ducts and providing adequate return air transfers, to mitigate the depressurization of the building.

- Encouraging the use of supply ventilation, by means of an outside air duct feeding into the main air return. (This provides ventilation only when the air handler operates.)

In these homes, the design goal for airtightness is 0.75 to $1.0 \mathrm{cfm}$ per square foot of floor area at $50 \mathrm{~Pa}$ (about 0.2 to 0.3 natural $\mathrm{ACH}$ in Florida), and the design goal for the mechanical ventilation system is $10 \mathrm{cfm}$ per person.

\section{Modeling Studies}

Several studies have been published in which a number of mechanical ventilation system designs are analyzed with computer simulation models and compared on the basis of performance and economics. The assumptions and methodologies vary widely among these studies, as do the conclusions. It appears that ventilation issues are so complex that, even under diligent analysis, the choice of a preferred approach is highly sensitive to a set of assumptions that are debatable. It is the opinion of this author that none of these studies definitively establishes a "best" approach to ventilation in any climate. Nonetheless, the recommendations are included in Table 2, in order to illustrate the diversity of ventilation strategies that are being recommended.

In a study entitled "Recommended Ventilation Strategies for Energy-Efficient Production Homes" conducted at LBNL (Roberson et al., 1998), nine candidate ventilation system configurations were simulated across four climate regions using the RESVENT ${ }^{7}$ and DOE-2 computer simulation models with typical meteorological year (TMY2) weather data. The systems are compared based on (1) total annualized cost, including capital and operating costs, (2) pressurization of the building, and (3) distribution of ventilation air within the home. The study concludes with specific system configuration recommendations for each climate. An interesting conclusion of this study is the recommendation of independently ducted multiport supply ventilation systems (Smp), as

7 "RESVENT is an hourly ventilation simulation program developed by the Energy Performance of Buildings Group at LBNL; it incorporates the Sherman-Grimsrud infiltration model." (Roberson et al., 1998) 
an alternative to forced-air-integrated systems. Quoting from Roberson et al. and adding notation per Section II:

All climates except Cold: Smp

"Based on the assumptions and analysis described in this report, we recommend independently ducted multiport supply ventilation in all climates except cold because the strategy provides the safety and health benefits of positive indoor pressure as well as the ability to dehumidify and filter ventilation air."

Cold climate: Bmp

"In cold climates, we recommend that multi-port supply ventilation be balanced by a single-port exhaust ventilation fan ..."

Cold climate: $\$ B h r$

"... and that builders offer balanced heat recovery ventilation to buyers as an optional upgrade."

All climates except cold, alternate design: (Sfa-r)

"For builders who continue to install forced-air integrated supply ventilation, we recommend ensuring ducts are airtight or in conditioned space, installing a control that automatically operates the forced-air fan 15-20 minutes during each hour that the fan does not operate for heating or cooling ..."

All climates except cold, alternate design: (\$Sfa-i)

“... and offering ICM forced-air fans to home buyers as an upgrade.

Some questions relating to these findings are still under investigation and include:

- The relative performance and cost-effectiveness of multiport (Smp) versus forced-airintegrated (Sfa) supply ventilation systems;

- The discrediting of depressurized systems in all cases; and

- Specific cost, configuration, and operation assumptions that are embedded in the analysis.

In a more recent study at LBNL, entitled "Selecting Whole-House Ventilation Strategies to Meet Proposed ASHRAE Standard 62.2: Energy Cost Considerations" (Wray et. al, 2000), four ventilation strategies were simulated across 22 climates using the RESVENT and DOE-2.1E models with TMY2 weather data. The systems are compared based on the ventilation operating cost-per-unit floor area. For existing homes that are relatively leaky, the study does not recommend mechanical ventilation. For new construction, the recommendations are as follows:

Esp or Ebr

The study recommends single-port exhaust systems or upgraded bathroom fans in many cases.

Bhr

For hot-humid climates, very tight envelopes, or cold climates with high energy prices, the study recommends HRV. 
This study does not address some important considerations, other than operating cost, in selecting a ventilation approach, such as:

- Ventilation effectiveness, i.e., the distribution of fresh air to all parts of the house; and

- The effects of depressurization (or the cost of mitigating the effects) on combustion backdrafting, garage fumes, or radon gas infiltration (moisture problems are addressed).

In a third study entitled "A Modeling Study of Ventilation in Manufactured Houses," conducted at the National Institute of Standards and Technology (Persily and Martin, 2000), the two most prevalent approaches to ventilation in manufactured housing - Ebr and Sfa - were simulated using the multizone airflow and contaminant dispersal model CONTAM. The recommendations involve how to allow for natural infiltration in the design, mechanical ventilation control strategy, and the reduction of duct leakage. However, they do not indicate the choice of one system type over another.

In an additional modeling study by Rudd (1998), a forced-air-integrated supply ventilation system is compared economically with the alternative of a separate continuous supply fan, over a wide range of climates. The results indicate that "net annual heating, cooling, and central fan operation costs ranged from \$36 to \$54 more for the central-fan-integrated system" with air ducts remaining in unconditioned spaces, and "ranged from \$50 more to \$33 less for the central-fan-integrated system" when moving the ducts into the conditioned space was included with the forced-air-integrated strategy.

\section{Unresolved Issues}

In this effort to compile an overview of residential ventilation systems, a number of unresolved issues have surfaced. In this section, these issues are described, as may be helpful in identifying needs for further research.

\section{Ventilation Consistency Requirement}

The ASHRAE standards specify minimum infiltration rates. How consistently must these rates be maintained in order to avoid adverse health effects? A definitive answer to this question may require research in the medical field. This concern applies to both natural and mechanical ventilation systems. See further discussion in Section I.B.

\section{Exhaust Ventilation Safety}

Exhaust ventilation systems are widely used in the Building America program, with some in each climate zone. This seems to be primarily due to the low cost of these systems. The teams generally use sealed venting of any combustion appliances in conditioned spaces. However, this addresses only one of the numerous concerns about exhaust ventilation (e.g., moisture, radon gas, fumes from garage; see Section I.D.4). How thoroughly and consistently are safety concerns resolved, in the exhaust ventilation systems used in the Building America program? 


\section{Adequacy of Occupant Control}

In some installations, the control of whole-house ventilation systems is left to the discretion of the occupants. Are occupants sufficiently aware of IAQ concerns and ventilation system design to properly control these systems? (See related discussion under the heading Natural Ventilation in Section I.D.3) Although written instructions may be provided to the occupants, how much time does the new homeowner spend reading them, along with all of the other necessary activities at that time? When occupant behavior is factored in, do these systems actually meet ventilation system performance standards?

\section{Forced-Air-Integrated Systems Issues}

A common approach to ventilation is to use the heating and cooling ductwork and blower to distribute outside air throughout the home. Usually, a small outside air duct feeds into the main return duct. This approach has some advantages: (1) a low first cost, (2) good ventilation effectiveness, in that fresh air is delivered to all rooms, and (3) positive house pressure, which is preferred in many cases. One of the concerns with this approach is the expense of running the main blower to provide ventilation even when heating or cooling is not needed (or underventilating at those times). More efficient ECM or ICM blowers can be used to reduce the operating expense, but these add substantially to the first cost and are seldom used. How economical are these systems, as typically installed and operated? Another potential problem is that air leakage from supply ducts outside of the pressure envelope may create a negative pressurization in the house, defeating the effort to maintain positive pressure. This appears to be the case in manufactured housing, where the ductwork is typically installed under the floor. How reliably are these systems maintaining positive house pressure? These questions may best be answered with field testing.

\section{Intermittently Balanced Systems}

In Section I.D.4, a "balanced" ventilation system is defined as one in which both intake and exhaust fans are used to maintain a neutral pressure within the building. In some systems, intake and exhaust fans are run at different times. For example, an upgraded bathroom exhaust fan may run on a timer schedule, while a forced-air-integrated supply system may run on a separate fan recycler control or merely based on thermostat operation. To what extent do these "intermittently balanced" systems mitigate the problems associated with positive and negative pressurization?

\section{$\underline{\text { Cost Constraint }}$}

Resistance to the adoption of new technologies that cost more can be significant. Given this constraint, the teams have had limited success marketing anything but the least expensive ventilation systems. Approaches such as consistently balanced systems, heat and energy recovery, and separate ventilation ductwork are rarely applied, and demand-controlled ventilation is virtually unheard of in residences. How can more effective approaches to residential ventilation best be promoted in the marketplace? 


\section{"Best" Approach to Ventilation}

The goals of the Building America program include energy-efficiency, comfort, health (air quality), and affordability. The design of a ventilation system involves trade-offs among these goals. For example, the most energy-efficient design that provides the most consistent air quality is not the least expensive design. Furthermore, the health implications of variable versus consistent and uniform IAQ are not well understood (see "Ventilation Consistency Requirement," above). It seems unlikely that all interested parties can even agree on an explicit definition of "best," let alone a determination of a best approach. It may make more sense to evaluate various systems on the basis of how well they meet each of the four goals, without trying to rank them.

\section{Mechanical versus Natural Ventilation}

There is definitely a trend toward tighter building envelopes and the use of mechanical ventilation systems in production housing. All of the Building America teams are pursuing this approach; three states require it; and the new draft ASHRAE residential ventilation standard nearly requires it. This seems to be a good trend, in that it promotes more consistent ventilation. However, the value of the added consistency is difficult to evaluate, because of the ambiguity of the ASHRAE standards in this regard.

\section{Diverse Approaches}

There is no consensus among the Building America teams as to the preferred approach to ventilation. Supply, exhaust, and balanced systems have each been installed in a wide variety of climates. All of the teams have some variation in their approaches, with IBACOS expressing the most diversity. BSC favors forced-air-integrated supply systems. CARB has used exhaust systems in cold climates and balanced systems in various climates. IHP prefers climate specific solutions; they have used exhaust systems in colder climates and are encouraging the use of supply systems in humid climates. Hickory uses both exhaust and intermittently balanced approaches. This experimental phase is useful in gaining a better understanding of the issues involved. However, there is also a need to converge on more specific guidance to the building industry regarding recommended designs, when enough experience has been gained to serve as a basis for such recommendations.

\section{$\underline{\text { Analyses are Inconclusive }}$}

The modeling studies that are cited in Section IV have not conclusively identified preferred approaches to ventilation in various climates. Because of the numerous unresolved issues in ventilation, the assumptions that are necessary for such an analysis are open to debate and difficult to resolve. (See, for example, "Best' Approach to Ventilation," above.)

\section{Acknowledgments}

The following Building America team members were very helpful in providing and discussing information essential to this study: Armin Rudd with BSC, Paul Raymer with Hickory, Brad Oberg and John Holton with IBACOS, Dianne Griffiths with CARB, and 
Subrato Chandra, Mike Lubliner and Neil Moyer with IHP. At NREL, Ren Anderson and Bob Hendron contributed significantly.

\section{References}

Andrews, S. (Dec. 2000). "The House as a System: Ventilation and IAQ." Home Builder (39:12); pp. 11-16.

ASHRAE (1993). ANSI/ASHRAE Standard 136-1993, A Method of Determining Air Change Rates in Detached Dwellings. Atlanta, GA: American Society of Heating, Refrigerating, and Air-conditioning Engineers, Inc.

ASHRAE (1997). ANSI/ASHRAE Standard 129-1997, Measuring Air-Change Effectiveness. Atlanta, GA: American Society of Heating, Refrigerating, and Airconditioning Engineers, Inc.

ASHRAE (1999). ASHRAE Standard 62-1999, Ventilation for Acceptable Indoor Air Quality. Atlanta, GA: American Society of Heating, Refrigerating, and Air-conditioning Engineers, Inc.

ASHRAE. 2000. BSR/ASHRAE Standard 62P, Ventilation and Acceptable Indoor Air Quality in Low-Rise Residential Buildings. Atlanta, GA: American Society of Heating, Refrigerating, and Air-conditioning Engineers, Inc.

Building America Home Page (2000).

http://www.eren.doe.gov/buildings/building_america/.

Dietz, R.N.; Goodrich, R.W.; Cote, E.A.; Wieser, R.F. (1986). "Detailed Description and Performance of a Passive Perfluorocarbon Tracer System for Building Ventilation and Air Exchange Measurements." Measured Air Leakage of Buildings, ASTM STP 904, H.R. Trechsel and P.L. Lagus, Eds. Philadelphia, PA: American Society for Testing and Materials, pp. 203-264.

Dorer, V; Breer, D. (1998). "Residential mechanical ventilation systems: performance criteria and evaluations." Energy and Buildings (27); pp. 247-255.

Emmerich, S.J.; Persily, A.K. (1997). "Literature Review on $\mathrm{CO}_{2}$-Based DemandControlled Ventilation." ASHRAE Transactions, Vol. 103, Part 2; pp. 229-243.

Fortmann, R.C.; Nagda, N.L.; Rector, H.E. (1990). "Comparison Of Methods For The Measurement Of Air Change Rates And Interzonal Airflows To Two Test Residences." In Air Change Rate And Airtightness In Buildings, pp. 104-18. ASTM STP 1067. M.H. Sherman, ed., American Society for Testing and Materials, West Conshohocken, PA.

Harrje, D.T.; Dutt, G.S.; Bohac, D.L.; Gadsby, K.J. (1985). "Documenting Air Movements And Infiltration In Multicell Buildings Using Various Tracer Techniques." ASHRAE Transactions 91(2): 2012-27.

Harrje, D.T.; Gadsby, K.J. (July 1986). "Some Residential Answers," ASHRAE Journal. 
Harrje, D.T.; Dietz, R.N.; Sherman, M.; Bohac, D.L.; D'Ottavio, T.W.; Dickerhoff, J.J. (1990). "Tracer Gas Measurement Systems Compared In A Multifamily Building." In Air Change Rate And Airtightness In Buildings, pp. 5-12. ASTM STP 1067. M.H. Sherman, ed., American Society for Testing and Materials, West Conshohocken, PA.

Hekmat, D.; Feustel, H.E.; Modera, M.P. (1986). "Impacts of Ventilation Strategies on Energy Consumption and Indoor Air Quality in Single-family Residences." Energy and Buildings, (9); pp. 239-251.

HUD (1994). Manufactured Home Construction and Safety Standards, Part 3280. U.S. Department of Housing and Urban Development.

Koontz, M.D.; Burruss, R.P.; Cade, D.R. (1995). Assessment of a Carbon Dioxide Controller for Residential Ventilation and Indoor Air Quality Management. Palo Alto, CA: Electric Power Research Institute; TR-104970.

Liddament, M.W. (2000). "A Review of Ventilation and the Quality of Ventilation Air. Indoor Air (10); pp.193-199.

Lubliner, M.; Gordon, A. (Sept. 26-29, 2000). "Ventilation in US Manufactured Homes: Requirements, Issues and Recommendations." The Hague, Netherlands: 21st Annual AIVC Conference.

Moyer, N.; Rudd, A.; Sherman, M.; Stevens, D. (May/June 2000). "Forum Brings Fresh Air to Ventilation Issues," Home Energy; pp. 15-19.

O'Neill, P. (1995). Field Demonstration of a Residential Ventilation Controller. Palo Alto, CA: Electric Power Research Institute; TR-104890.

Persily, A.K.; Martin, S.R. (2000). A Modeling Study of Ventilation in Manufactured Houses. Gaithersburg, MD: National Institute of Standards and Technology; NISTIR 6455.

Raymer, P.; Kelley, M.E. (2000). "Analysis of Current Practice and Advanced Ventilation Strategies for Residential Buildings." Cambridge, MA: Hickory Consortium; Deliverable 2.A.1, Task Order No. KAR-5-18413-02.

Reardon, J.T.; Shaw, C. (1997). "Evaluation of Five Simple Ventilation Strategies Suitable for Houses Without Forced-Air Heating." ASHRAE Transactions Vol 103, Pt 1, p 731-744.

Roberson, J.A.; Brown, E.B.; Koomey, J.G.; Greenberg, S.E. (1998). Recommended Ventilation Strategies for Energy-Efficient Production Homes. Berkeley, CA: Lawrence Berkeley National Laboratory; LBNL-40478. http://enduse/lbl/gov/projects/ESVentilation.

Rudd, A.F. (1998). "Design/Sizing Methodology and Economic Evaluation of CentralFan-Integrated Supply Ventilation Systems." Proceedings of the 1998 ACEEE Summer Study on Energy Efficiency in Buildings, 23-28 August, Pacific Grove, California. Washington, D.C: American Council for an Energy-Efficient Economy. 
Rudd, A.F.; Lstiburek, J.W. (2000). "Measurement of Ventilation and Interzonal Distribution in Single-Family Homes." ASHRAE Transactions 2000, MN-00-10-3, V. 106, Pt.2. Atlanta, GA: American Society of Heating Refrigeration and Air-Conditioning Engineers.

Schell, M.; Int-Hout, D. (Feb., 2001). "Demand Control Ventilation Using $\mathrm{CO}_{2} . "$ ASHRAE Journal.

Sherman, M.H.; Modera, M.P. (1986). "Comparison of Measured and Predicted Infiltration Using the LBL Infiltration Model." Measured Air Leakage of Buildings, ASTM STP 904, H.R. Trechsel and P.L. Lagus, Eds. Philadelphia, PA: American Society for Testing and Materials; pp. 325-347.

Sherman, M.H.; Dickerhoff, D. (1989). "A Multi-Gas Tracer System for Multi-Zone Airflow Measurements." Proceedings of the ASHRAE/DOE/BTECC/CIBSE Conference Thermal Performance of the Exterior Envelopes of Buildings IV, pp. 417-32.

Sinden, F.W. (1978). "Multi-Chamber Theory Of Air Infiltration." Building and Environment 13:21-28.

Steven Winter Associates (1998). "Letter Report: Analysis of Advanced Space Conditioning and Ventilation Strategies." Consortium for Advanced Residential Buildings, Deliverable 2.A.1, Task Order No. KAR-8-18411-02.

Stevens, D. (March/April 1996). "Mechanical Ventilation for the Home" Home Energy; pp. 13-19.

Strindehag, O.I.; Norell, L.; Kvarnström, S. (1990). "Improved Indoor Air Quality by Supervision of the $\mathrm{CO}_{2}$ Content." Indoor Air 90, Proceedings of the 5th International Conference on Indoor Air Quality and Climate 4; pp. 317-322.

Strindehag, O.; Persson, P.G. (Feb. 1989). "Auditorium with demand-controlled ventilation." Air Infiltration Review, Vol. 10, No. 2.

Woolliscroft, M. (1997). "Residential Ventilation in the United Kingdom: An Overview," ASHRAE Transactions, v. 103, n. 1.

Wray, C.P.; Matson, N.E.; Sherman, M.H. (2000). Selecting Whole House Ventilation Strategies to Meet Proposed ASHRAE Standard 62.2: Energy Cost Considerations. ASHRAE Transactions, Vol. 106, Part II. Also (1998) Berkeley, CA: Lawrence Berkeley National Laboratory; LBNL-44479; http://emduse/lbl/gov/projects/ESVentilation. 


\section{Appendix: Climate Zones Defined}

\section{Severe-Cold}

A severe-cold climate is defined as a region with approximately 8,000 heating degreedays or greater.

\section{Cold}

A cold climate is defined as a region with approximately 4,500 heating degree-days or greater and less than approximately 8,000 heating degree-days.

\section{Mixed-Humid}

A mixed-humid climate is defined as a region that receives more than 20 inches of annual precipitation, has fewer than 4,500 heating degree days or less, and where the monthly average outdoor temperature drops below $45^{\circ} \mathrm{F}$ during the winter months.

\section{Hot-Humid}

A hot-humid climate is defined as a region that receives more than 20 inches of annual precipitation and where the monthly average outdoor temperature remains above $45^{\circ} \mathrm{F}$ throughout the year.

The definition characterizes a region that is almost identical to the ASHRAE definition of hot-humid climates where one or both of the following occur:

- A $67^{\circ} \mathrm{F}$ of higher wet bulb temperature for 3,000 or more hours during the warmest six consecutive months of the year; or

- $\mathrm{A} 73^{\circ} \mathrm{F}$ or higher wet bulb temperature for 1,500 or more hours during the warmest six consecutive months of the year.

\section{Hot-Dry/Mixed-Dry}

A hot-dry climate is defined as a region that receives less than 20 inches of annual precipitation and where the monthly average outdoor temperature remains above $45^{\circ} \mathrm{F}$ throughout the year.

A mixed-dry climate is defined as a region that receives less than 20 inches of annual precipitation, has approximately 4,500 heating degree days or less, and where the monthly average outdoor temperature drops below $45^{\circ} \mathrm{F}$ during the winter months.

Ref:

The information presented above was developed by the Building Science Corporation based on Herbertson's Thermal Regions, a modified Koppen classification, the ASHRAE definition of hot-humid climates and average annual precipitation from the U.S. Department of Agriculture. 


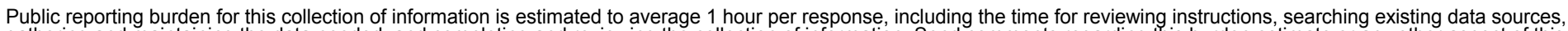

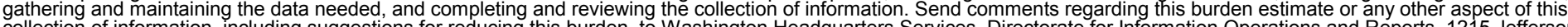

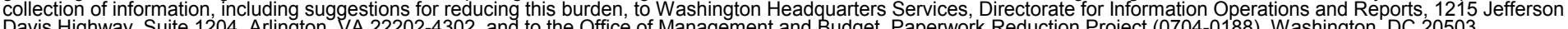

Davis Highway, Suite 1204, Arlington, VA 22202-4302, and to the Office of Management and Budget, Paperwork Reduction Project (0704-0188), Washington, DC 20503.
1. AGENCY USE ONLY (Leave blank)
2. REPORT DATE
May 2001
3. REPORT TYPE AND DATES COVERED
Technical Report

4. TITLE AND SUBTITLE

An Overview of Residential Ventilation Activities in the Building America Program (Phase I)

6. $\mathrm{AUTHOR}(\mathrm{S})$

Dennis Barley

7. PERFORMING ORGANIZATION NAME(S) AND ADDRESS(ES)

National Renewable Energy Laboratory

1617 Cole Blvd.

Golden, CO 80401-3393

9. SPONSORING/MONITORING AGENCY NAME(S) AND ADDRESS(ES)

National Renewable Energy Laboratory

1617 Cole Blvd.

Golden, CO 80401-3393

5. FUNDING NUMBERS

BET1.8004

11. SUPPLEMENTARY NOTES

12a. DISTRIBUTION/AVAILABILITY STATEMENT

National Technical Information Service

12b. DISTRIBUTION CODE

U.S. Department of Commerce

5285 Port Royal Road

Springfield, VA 22161

13. ABSTRACT (Maximum 200 words)

This report provides an overview of issues involved in residential ventilation; provides an overview of the various ventilation strategies being evaluated by the five teams, or consortia, currently involved in the Building America Program; and identifies unresolved technical issues.

14. SUBJECT TERMS

Building America; residential ventilation

15. NUMBER OF PAGES

16. PRICE CODE

17. SECURITY CLASSIFICATION OF REPORT

Unclassified

NSN 7540-01-280-5500
8. PERFORMING ORGANIZATION REPORT NUMBER NREL/TP-550-30107

10. SPONSORING/MONITORING AGENCY REPORT NUMBER
9. SECURITY CLASSIFICATION OF ABSTRACT

Unclassified
20. LIMITATION OF ABSTRACT

UL
OF THIS PAGE

Unclassified 